\title{
INTESTINAL SPIROCHETOSIS: FIRST CASES REPORTED IN BRAZIL AND THE USE OF IMMUNOHISTOCHEMISTRY AS AN AID IN HISTOPATHOLOGICAL DIAGNOSIS.
}

\author{
T. DE BRITO, Marina P. SANDOVAL, Ana G. SILVA, R. C. SAAD \& W. COLAIACOVO
}

\begin{abstract}
SUMMARY
Colonization of the colon and rectum by intestinal spirochetes is detected for the first time in Brazil in 4 of $282(1.41 \%)$ patients who had undergone sigmoidoscopy and/or colonoscopy with a histopathological diagnosis of chronic non specific-colitis. This frequency is probably understimated, since surgically obtained specimens were not considered in the present study.

Histopathological diagnosis was performed using routine stains like hematoxylin-eosin which showed the typical, of 3- $\mu \mathrm{m}$ thick hematoxyphilic fringe on the brush border of the surface epithelium, and by silver stains like the Warthin-Starry stain. Immunohistochemical procedures using two, polyclonal, primary antibodies, one against Treponema pallidum and the other against Leptospira interrogans serovar copenhageni serogroup Icterohaemorrhagiae cross-reacted with spirochetal antigen/s producing a marked contrast of the fringe over the colonic epithelium, preserving the spiral-shaped morphology of the parasite. In one case with marked diarrhea, immunohistochemistry detected spirochetal antigen/s within a cell in an intestinal crypt, thus demonstrating that the infection can be more widely disseminated than suspected using routine stains. Immunohistochemical procedures, thus, greatly facilitate the histological diagnosis of intestinal spirochetosis and may contribute to a better understanding of the pathogenesis of the disease.

Transmission and scanning electron microscopy performed in one case showed that the spirochete closely resembled the species designated as Brachyspira aalborgi.
\end{abstract}

KEYWORDS: Intestinal Spirochetosis, Brachyspira aalborgi, Immunohistochemistry, Antileptospiral and anti-treponemal sera, Antigen detection.

\section{INTRODUCTION}

Human intestinal spirochetosis was first described by HARLAND \& LEE" ${ }^{11}$ and LEE et $\mathrm{al}^{14}$. The term defines the colonization of the surface epithelium of the colon and of the appendix ${ }^{19,22}$ by spirochetes.

Ordinary staining techniques like hematoxylineosin and silver impregnation are usually considered sufficient to demonstrate colonic infestation ${ }^{6.26}$. There is a single short mention by COTTON et al..$^{5}$ of the use of an anti-treponemal anti-serum raised in rabbits against Treponema pallidum in an immunoperoxidase system to stain intestinal spirochetes.

To our knowledge, there have been no previous

Institute of Tropical Medicine and University Hospital, University of S. Paulo Medical School, S. Paulo, Brazil.

Correspondence to: Thales De Brito, M.D.; Instituto de Medicina Tropical de S. Paulo (II), $2^{\circ}$ andar, sala 5; Av. Dr. Enéas de Carvalho Aguiar, 470 , 05403-000 São Paulo, SP, Brazil. 
DE BRITO, T.; SANDOVAL, M. P.; SILVA, A. G.; SAAD, R. C. \& COLAIACOVO, W. - Intestinal spirochetosis: first cases reported in Brazil and the use of immunohistochemistry as an aid in histopathological diagnosis. Rev. Inst. Med. trop. S. Paulo, 38(1): 45-53, 1996.

reports of intestinal spirochetosis in Brazil. The purpose of this paper is to describe the first four cases of spirochetosis in this country, from 282 colonic biopsies performed in a regional, general hospital, serving a population of some 750,000 . We also demonstrate that a more accurate histological diagnosis can be obtained when immunohistochemical techniques are used.

\section{PATIENTS AND METHODS}

Routine rectosigmoidal biopsies, usually multiple, were taken after sigmoidoscopy and/or colonoscopy from 282 patients with different clinical symptoms, usually diarrhea, intestinal bleeding and chronic constipation. Histopathological diagnosis was mainly of chronic, non-specific colitis. A few biopsies were performed during surgical procedures. Patients' age ranged from 5 months to 92 years with an average of 52 years. There were 126 males and 156 females.

Intestinal spirochetosis was first detected in patient 1 (see Table 1). A subsequent, retrospective study of rectal and colonic biopsies detected three more cases. The frequency of intestinal spirochetosis in our material was $1.41 \%$.

Light microscopy: biopsy specimens were fixed in $10 \%$ buffered, neutral formalin; paraffin embedded sections were stained with hematoxylin-eosin (HE) and, when necessary by PAS (periodic acid Schiff reaction) and Brown-Hopps for bacteria. Biopsies of the four cases of spirochetosis were also stained using a modified Warthin-Starry method (Armed Forces Institute of Pathology - USA - modification) for spirochetes.

Ultrastructural studies: performed only in patient 1. For transmission electron microscopy, small fragments of colonic mucosa were fixed in $2 \%$ glutaraldehyde, post fixed in $1 \%$ osmium tetroxide, dehydrated in graded ethanols and embedded in Araldite. Thick sections were stained with toluidine blue and azure II for selection of tissue for the ultrastructural study. Thin sections were stained with uranyl acetate and lead citrate and examined in a JEOL 1010 transmission electron microscope.

For scanning electron microscopy, tissue fragments were fixed for 6 hours in $2 \%$ glutaraldehyde in $0.1 \mathrm{M}$ cacodylate buffer, $\mathrm{pH} 7.2$, dehydrated in ethanol, critical point dried, shadow cast with gold, and examined in a Cambridge Stereoscan 240 .

Immunohistochemistry: performed in all four cases of proven intestinal spirochetosis, and in colonic biopsies where the disease was suspected to be present.

For the immunohistochemical procedures, $4-5-\mu \mathrm{m}$ thick sections from paraffin blocks were mounted on

TABLE 1

MAIN CLINICAL FEATURES IN FOUR CASES OF INTESTINAL SPIROCHETOSIS

\begin{tabular}{|c|c|c|c|c|c|c|}
\hline $\begin{array}{l}\text { PATIENT } \\
\text { NUMBER }\end{array}$ & SEX & $\begin{array}{c}\text { AGE } \\
\text { (YEARS) }\end{array}$ & COMPLAINT & $\begin{array}{l}\text { DURATION OF } \\
\text { SYMPTOMS } \\
\text { (MONTHS) }\end{array}$ & $\begin{array}{l}\text { CLINICAL } \\
\text { DIAGNOSIS }\end{array}$ & $\begin{array}{c}\text { COLONOSCOPY AND/OR } \\
\text { SIGMOIDOSCOPY FINDINGS }\end{array}$ \\
\hline 1 & $\mathrm{~F}$ & 37 & $\begin{array}{l}\text { Diarrhea } \\
\text { and } \\
\text { abdominal } \\
\text { pain }\end{array}$ & 9 & $\begin{array}{l}\text { Diarrhea of } \\
\text { unknown } \\
\text { etiology }\end{array}$ & $\begin{array}{l}\text { Presence of vascular red rings } \\
\text { in the colon: Ulcerative colitis? }\end{array}$ \\
\hline 2 & $\mathrm{~F}$ & 60 & $\begin{array}{l}\text { Epigastric } \\
\text { discomfort } \\
\text { and } \\
\text { constipation }\end{array}$ & 96 & $\begin{array}{l}\text { No definite } \\
\text { clinical } \\
\text { diagnosis }\end{array}$ & $\begin{array}{l}\text { Elevation at the ileo-cecal } \\
\text { valve (probably sub-mucosal } \\
\text { lipoma) }\end{array}$ \\
\hline 3 & M & 50 & $\begin{array}{l}\text { Intermitent } \\
\text { rectal } \\
\text { bleeding }\end{array}$ & 3 & $\begin{array}{l}\text { Carcinoma } \\
\text { of rectum }\end{array}$ & Carcinoma of rectum \\
\hline 4 & M & 11 & $\begin{array}{l}\text { Chronic } \\
\text { constipation }\end{array}$ & 24 & $\begin{array}{l}\text { Congenital } \\
\text { megacolon }\end{array}$ & Megacolon \\
\hline
\end{tabular}


DE BRITO, T.; SANDOVAL, M. P.; SILVA, A. G.; SAAD, R. C. \& COLAIACOVO, W. - Intestinal spirochetosis: first cases reported in Brazil and the use of immunohistochemistry as an aid in histopathological diagnosis. Rev. Inst. Med. trop. S. Paulo, 38(1): 45-53, 1996.

poly-L-lysine coated slides. Endogenous peroxidase activity was inhibited by incubation with $3 \% \mathrm{H}_{2} \mathrm{O}_{2}$ in methanol for $20 \mathrm{~min}$.

Two primary antibodies were used. The first, a rabbit, anti-Treponema pallidum serum was obtained after intra-testicular inoculation of rabbits with $1 \mathrm{ml}$ of Treponema pallidum, Nichols strain, in saline containing about 100 viable treponemes per microscopic field. After 10 days $1 \mathrm{ml}$ of saline containing viable treponemes was injected by venous route. This procedure was repeated every 5 days during a 40-day period. The rabbits were then bled and the sera purified with $40 \%$ ammonium sulphate and caprilic acid. The immunological activity of the rabbit IgG anti Treponema pallidum was evaluated by indirect immunofluorescence and hemagglutination tests, and this antibody was used in the immunohistochemical test, diluted 1:4,000 in phosphate buffered saline (PBS), an optimal dilution.

The second antibody, a rabbit anti-serum to leptospires was produced by immunizing rabbits with sequential doses of $1,2,4$ and $4 \mathrm{ml}$ suspensions of $L$. interrogans serovar copenhageni serogroup Icterohaemorrhagiae at 1-week intervals; the animals were bled 7 days after the last inoculation. The microscopic agglutination test revealed a 1:6,400 titre. The IgG, obtained by sodium sulphate fractionation, dialysed and purified in Sephadex 6100 and DEAE cellulose, was used at an optimal dilution of 1:3,000 in PBS.

The anti-leptospire serum was used after microwave pretreatment of deparaffinized sections. Sections were placed in sodium citrate buffer $(0.01 \mathrm{M}$ sodium citrate monohydrate, $\mathrm{pH}$ 6.0) in Coplin jars and heated for $2 \times 9 \mathrm{~min}$ in a domestic microwave oven at maximum output. After cooling to room temperature, the slides were rinsed initially in tap water, then in distilled water and finally in PBS.

The slides were then incubated overnight at $4^{\circ} \mathrm{C}$ with each anti-serum. The secondary antibody was biotinylated goat, anti-rabbit immunoglobulin 1:2,000 (Vector Laboratories, Burlingame, CA). Avidin-biotinperoxidase complex (ABC) 1:200 (Vector) was used as the amplification step of the reaction ${ }^{13}$. Signal development was obtained using $\mathrm{H}_{2} \mathrm{O}_{2}$ as the substrate and $3,3^{\prime}$, $5,5^{1}$ diaminobenzidine tetrachloride (Sigma). The sections were lightly counterstained with hematoxylin.
Substitution of the primary antibody by (pre immune) rabbit serum applied to the sections yielded negative results. The reaction of both primary antibodies on sections of colon mucosa with chronic, nonspecific colitis was also negative.

\section{RESULTS}

The main clinical features of the four cases of intestinal spirochetosis are given in Table 1. None of the patients was human immunodeficiency virus (HIV) positive.

Colorectal spirochetosis was diagnosed by light microscopy in all four cases in HE-stained sections by the presence of a 3- $\mu \mathrm{m}$ thick, light blue hematoxyphilic (basophilic) fringe on the brush border of the surface epithelium, (Fig. 1A). At higher magnification the fringe was seen to consist of a line of numerous, thin, rod-like or sinusoidal microorganisms that covered the surface of the epithelium, interrupted only by globet cells. The epithelial cells appeared to be undamaged but a slight, chronic, non specific, inflammatory reaction was observed in the underlying mucosa in all four cases. In case 1 alone, the basophilic fringe extended significantly into the crypts. Warthin-Starry staining confirmed the diagnosis, resulting in high contrast staining of the spirochetes (Fig. 1B).

Both anti-sera were seen to cross-react with spirochetal antigens, producing a marked contrast of the fringe detected over the surface epithelium and preserving the spiral shaped morphology of the parasite (Fig. 1C, 1D). In case 1, isolated epithelial cells in the crypts exhibited antigen deposits in the cytoplasm (Fig. 1C). In the other patients, the antigen deposits were restricted to the fringe over the intestinal epithelium.

Transmission electron microscopy revealed many spirochetes with tapered ends oriented at right angles to the epithelial surface and attached end-on to the luminal cell membrane between the microvilli (Fig. 2). The spirochetes measured 3 to $4 \mu \mathrm{m}$ in length and 0.2 $\mu \mathrm{m}$ in width. The microvilli appeared shortened or even depleted in proportion to the density of the attached spirochetes. The epithelial surface membrane at the attachment site was depressed to form a small, electron-lucent pit between the tip of the organism and the cell membrane (Fig. 3). A zone of electron-dense material was present just beneath the cell membrane at the point of contact. The spirochetes themselves were 
DE BRITO, T.; SANDOVAL, M. P.; SILVA, A. G.; SAAD, R. C. \& COLAIACOVO, W. - Intestinal spirochetosis: first cases reported in Brazil and the use of immunohy jochemistry as an aid in histopathological diagnosis. Rev. Inst. Med. trop. S. Paulo, 38(1): 45-53, 1996.
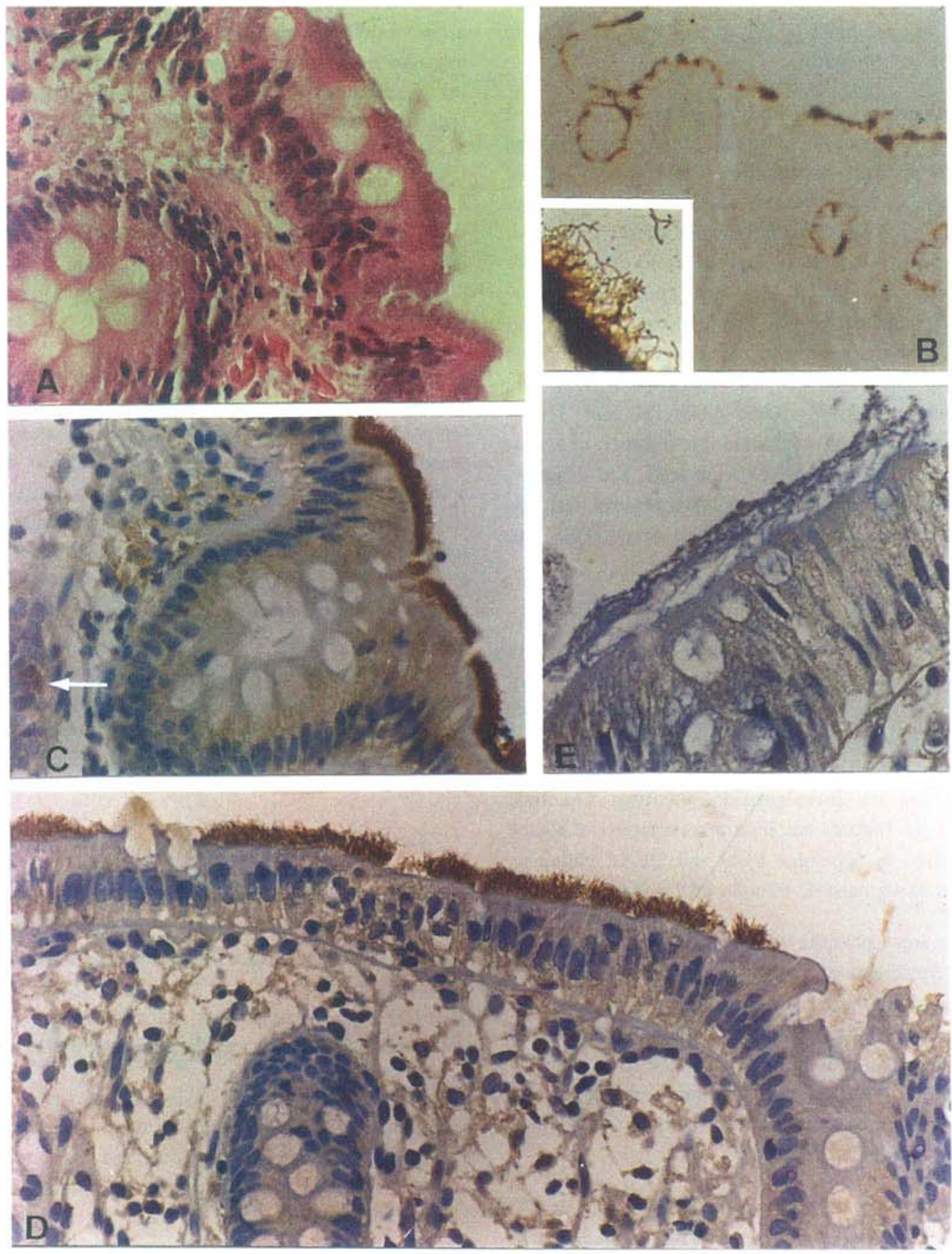

Fig. ( A) Basophilic fringe on the brush border of the surface epithelium. Epithelial cells appear undamaged but a slight, chronic, non-specific, inflammatory reaction is observed in the mucosa. Patient $1-H E x 800$. B) Silver staining contrasts the fringe on the surface epithelium which extends into the crypts. $\mathrm{x} 300$. Insert shows the spirochetes which make up the silver stained fringe in detail $x$ 900. Patient $l$ - Warthin-Starry stain. C) Anti-treponemal serum cross reacts whith the spirochetal antigen/s on the surface epithelium and at marked antigenic site in an isolated crypt cell (arrow). Patient $I$. Immunohistochemistry and hematoxylin x 500. D) Anti-leptospiral serum also cross-reacts with spirochetal antigen/s on the surface epithelium providing sharp contrast and preserving the spiral-shaped morphology of the parasite. Patient 2 - Immunohistochemistry and hematoxylin $x 800$.E) Patient with chronic, non-specific colitis with mucus deposit over the epithelium which may be initially mistaken as the hematoxyphilic fringe of intestinal spirochetosis. Immunohistochemistry showed negative results. Anti-treponemal anti-serum and hematoxylin $x 800$. 
DE BRITO, T.; SANDOVAL, M. P.; SILVA, A. G.; SAAD, R. C. \& COLAIACOVO, W. - Intestinal spirochetosis: first cases reported in Brazil and the use of immunohistochemistry as an aid in histopathological diagnosis. Rev. Inst. Med. trop. S. Paulo, 38(1): 45-53, 1996.
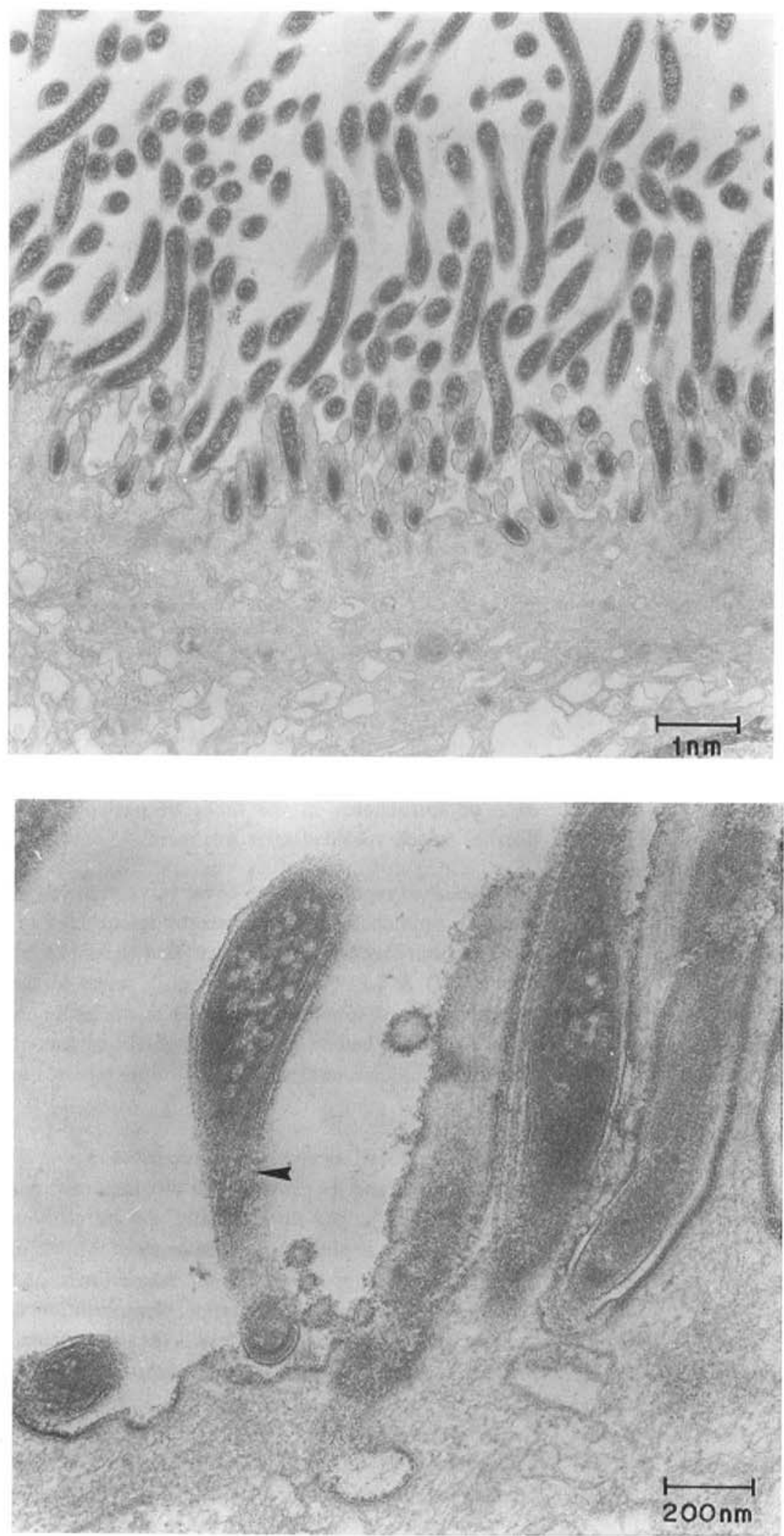

Fig. 2 - Spirochetes oriented at right angles to the epithelial surface and attached end-on to the luminal cell membrane between the microvilli.

Fig. 3 - The epithelial surface membrane at the attachment site is depressed to form a small electron-lucent pit between the organism and the cell membrane. Spirochetes possess a double unit membrane and flagella (arrows-head). Ribosomes and nuclear material can be recognized within the cells. 
DE BRITO, T.; SANDOVAL, M. P.; SILVA, A. G.; SAAD, R. C. \& COLAIACOVO, W. - Intestinal spirochetosis: first cases reported in Brazil and the use of immunohistochemistry as an aid in histopathological diagnosis. Rev. Inst. Med. trop. S. Paulo, 38(1): 45-53, 1996.

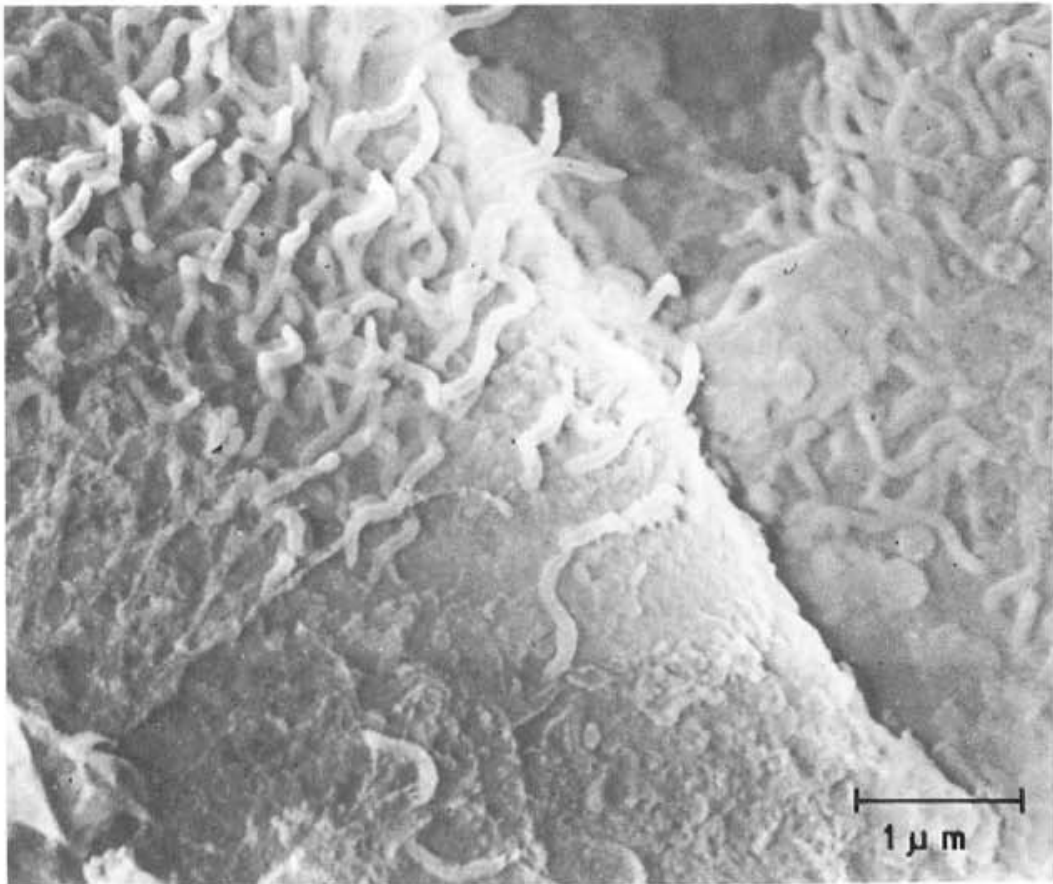

Fig. 4 - Scanning electron microscopy shows that the normal surfacemorphology is obliterated by the presence of many spiral-shaped organisms. enveloped by two asymmetrical unit membranes, the outer leaflets being slightly thicker and more electron dense than the inner leaflets. Ribosomes and nuclear material could be recognized within the cells (Fig. 3). Six to eight axial flagella located in the periplasmic space were particularly visible in transverse sections of the parasite.

Scanning electron microscopy revealed the mucosal surface to consist of polygonal units delineated by a shallow depression or furrow. Small pits were seen, representing goblet cells that had discharged their mucin. The normal surface morphology was obliterated by the presence of many spiral-shaped microorganisms usually lying at right angles to the surface and projecting into the lumen (Fig. 4). At no point could the normal surface microvilli of the epithelial cells be discerned.

\section{DISCUSSION}

Since the end of last century, spirochetes are known to be present in the feces of various animal species, including the monkey and man. Good historical surveys of spirochetosis of the digestive tract are covered in the works of TAKEUCHI et al. ${ }^{25}$ and TEGLBJAERG ${ }^{26}$.
In Brazil, early reports by LINS in $1924^{18}$ and by GOMES \& PESSOA in $1926^{\circ}$ demonstrated the presence of spirochetes in the feces of patients with diarrhea which subsided after treatment.

Published reports seem to cover two conditions of intestinal spirochetosis; one concerns spirochetes recovered from faeces and the other, first described by HARLAND \& LEE $^{\prime \prime}$ and LEE et al. ${ }^{14}$, refers to the demonstration of spirochetes attached to mucosal surfaces. Our cases belong to this latter condition and, as far as we could ascertain, are the first to be reported in Brazil.

Intestinal spirochetosis appears to be a worldwide condition and its geographical distribution varies considerably as judged histologically and by electron microscopy. It was present at a frequency of $2.5-9 \%$ in an unselected biopsy series from Scandinavia and Great Britain ${ }^{17}$. In northern Europe, the condition is seen in $3-9 \%$ of all patients referred for colonoscopic biopsies ${ }^{16}$; a frequency of $16.5 \%$ has been reported for Greece $^{7}$. TAKEUCHI et al. ${ }^{25}$ reported a frequency of intestinal spirochetosis of $1.9 \%$ in the USA. We found a frequency of intestinal spirochetosis of $1.41 \%$ in patients undergoing colorectal biopsies. This figure probably underestimates the real frequency of the con- 
DE BRITO, T.; SANDOVAL, M. P.; SILVA, A. G.; SAAD, R. C. \& COLAIACOVO, W. - Intestinal spirochetosis: first cases reported in Brazil and the use of immunohistochemistry as an aid in histopathological diagnosis. Rev. Inst. Med. trop. S. Paulo, 38(1): 45-53, 1996.

dition in Brazil since surgical specimens were not included in the study. The frequency of intestinal spirochetosis in the appendix varies from $7.8 \%$ to $12.3 \%$ as reported in Argentina, England, Sweden and Denmark 14,19.22.27.

Successful isolation, cultivation and propagation of spirochetes from feces or from human rectal biopsies has been reported. The growth characteristics and the morphology of the spirochetes differ sufficiently from previously isolated treponemes to justify a new designation, and the name Brachyspira aalborgi has been proposed for the new type species isolated in the Scandinavian countries ${ }^{12}$. The spirochetes in our case 1 closely resembles this species morphologically. Other spirochetes were distinguishable by ultrastructural and growth aspects ${ }^{2.7 .10}$ and by genetic characterization ${ }^{15}$.

Bacteriological techniques for the identification of intestinal spirochetes have been difficult to carry out routinely and ordinary staining techniques were considered sufficient for the histological diagnosis of the condition $^{6}$. Hematoxylin-eosin discloses the presence of a $3-\mu \mathrm{m}$ thick hematoxyphilic, fuzzy layer on the luminal surface of the epithelial cells of the rectum, colon and appendix. The presence of spirochetes can be confirmed using silver stains like the Warthin-Starry stain. Transmission and scanning electron microscopy also have been used to demonstrate the spirochetes attached to the epithelial surfaces. Curiously, spirochetal infection ceases abruptly on neoplastic epithelium but involves metaplastic polyps $s^{3.14}$.

Immunohistochemical procedures using both anti-treponemal and anti-leptospire anti-sera were now shown to cross-react with spirochetal antigen/s and consequently to facilitate the diagnosis of intestinal spirochetosis. The use of immunohistochemistry has allowed the localization of antigen deposits within epithelial cells, revealing that in certain cases, the infection is more widely disseminated than suspected by ordinary routine stains. None of our patients had clinical or serological evidence of syphilis or leptospirosis.

Spirochetes are known to be involved in certain enteropathies in animals; however, the pathological potential and clinical significance of human intestinal spirochetosis is still controversial. Indeed, several reports have considered these organisms to be commensals of the gastrointestinal tract ${ }^{14.21 .26}$. Other studies have suggested that intestinal spirochetosis may cause rectal discharge, rectal bleeding and diarrhea and that the successful treatment of intestinal spirochetosis improves these clinical symptoms $s^{4,8,23}$. Damage to epithelial cells and the penetration of the spirochetes into the lamina propria with engagement of macrophages have been described ${ }^{1}$ and are considered to be the primary cause of the clinical symptoms. GAD et al. $^{8}$ ascribed the pathogenicity of the microorganisms to the extent and degree of infection. These authors suggest that the presence of a thick layer of organisms on the surface epithelium of the colon may act as a mechanical barrier to the reabsorptive processes in the large bowel lumen, leading to the watery diarrhea.

In three of our patients, the main clinical symptoms were unrelated to spirochetosis and therefore the spirochetes may be regarded as inocuous commensals. The parasites and their antigen/s were restricted to the luminal aspect of the epithelial cells in these patients. However, in case 1, a patient with marked diarrhea, the parasites and their antigen/s were widely more disseminated. Since this patient improved after metronidazole treatment and the spirochetes disappeared from the control biopsy it is possible that in this particular case the diarrhea may have been caused by the spirochetal infection. Colonoscopic findings in this patient were non-specific and revealed vascular rings in the colon. This aspect, which resembles that seen in ulcerative colitis did not disappear after treatment.

The high prevalence ( 30 to $36 \%$ ) of intestinal spirochetosis in homosexual men accompanied by more extensive histopathological changes should be regarded as an alert for spirochetosis acting as another opportunistic infection in immunosuppressed patients $s^{2 \cdot 10.20 .24}$. The use of immunohistochemical procedures would be helpful in evaluating the dissemination of the microorganism and/or their antigens.

In conclusion, intestinal spirochetosis is usually a harmless infection of the gastrointestinal tract, but a host factor or factors may upset the balance of the bacterial flora in the gut, leading to an overgrowth of the spirochetes which may then become pathogenic.

\section{RESUMO}

Espiroquetose intestinal: primeiros casos no Brasil e o uso de técnicas imunohistoquímicas como ajuda no diagnóstico histopatológico

A colonização do colo e reto por espiroquetas intestinais foi detectada pela primeira vez no Brasil em 4 de $282(1,41 \%)$ pacientes submetidos a sigmoi- 
DE BRITO, T.; SANDOVAL, M. P.; SILVA, A. G.; SAAD, R. C. \& COLAIACOVO, W. - Intestinal spirochetosis: first cases reported in Brazil and the use of immunohistochemistry as an aid in histopathological diagnosis. Rev. Inst. Med. trop. S. Paulo, 38(1): 45-53, 1996.

doscopia e/ou colonoscopia com o diagnóstico histopatológico de colite crônica inespecífica. A frequência é provavelmente menor que a real, uma vez que espécimens cirúrgicos não foram considerados no presente estudo.

O diagnóstico histopatológico foi feito através de colorações de rotina, tais como a hematoxilina-eosina, que mostraram franja basofilica de $3 \mu$ de espessura sobre a borda em escova do epitélio e por impregnações pela prata como o método de Whartin-Starry. Métodos imunohistoquímicos, usando dois soros primários policlonais, um contra o Treponema pallidum $\mathrm{e}$ o outro contra Leptospira interrogans, serovar copenhageni serogrupo Icterohaemorrhagiae revelaram reatividade cruzada com os antígeno/s dos espiroquetas produzindo um contraste acentuado da franja sobre o epitélio colônico e preservando a morfologia espiralada do parasita. Em um paciente, com acentuada diarréia, a imunohistoquímica detectou antígenos de espiroqueta no citoplasma de uma célula da cripta intestinal, demonstrando que a infecção estava mais disseminada do que parecia pelas colorações comuns. Portanto, os métodos imunohistoquímicos facilitam o diagnóstico histológico da espiroquetose intestinal e podem, também, contribuir para a melhor compreensão da patogenia da doença.

A microscopia eletrônica de transmissão e a microscopia de varredura, realizadas em um paciente, demonstraram que os espiroquetas lembram a espécie designada como Brachyspira aalborgi.

\section{ACKNOWLEDGEMENTS}

Financial support for this project was provided by a grant from CNPq (300857/94-2) and by LIM-03 and LIM-06 "Hospital das Clínicas". We thank Miss Maria Eli P. de Castro for secretarial help.

\section{REFERENCES}

1. ANTONAKOPOULOS, G.; NEWMAN, J. \& WILKINSON, M.Intestinal spirochetosis: an electron microscopic study of an unusual case. Histopathology, 6: 477-488, 1982.

2. COOPER, C.; COTTON, D.W.K.; HUDSON, M.J.; KIRKHAM, N. \& WILMOTT, E.E.W.- Rectal spirochetosis in homosexual men: characterization of the organism and pathophysiology. Genitourin. Med., 62: 47-52, 1986.

3. COYNE, J.O.; CURRY, A.; PURNELL, P. \& HABOUBI, N.T. Colonic tubular adenomas and intestinal spirochaetosis: an incompatible association. Histopathology, 27: 377-379, 1995.
4. CRUCIOLI, V. \& BUSUTTIL, A. - Human intestinal spirochetosis. Scand. J. Gastroent., 70: 177-179, 1981.

5. COTTON, D.W.K.; KIRKHAM, N. \& HICKS, D.A. - Rectal spirochetosis. Brit. J. vener. Dis., 60: 106-109, 1984.

6. DAUZAN, Y.R.; MERLIO, J.P.H.; GRELIER, P. et al. - La spirochétose colo-rectale: une entité anatomo-pathologique? Ann. Path., 10: 258-261, 1990 .

7. DELLADETSIMA, K.; MARKAKI, S. \& PAPADIMITRIOU, K. - Intestinal spirochetosis. Light and electron microscopic study. Path. Res. Pract., 182: 780-782, 1987.

8. GAD, A.; WILLÉN, R.: FURUGARD, K.; FORS, B. \& HRADSKY. M. - Intestinal spirochetosis as a cause of long standing diarrhea. Upsala J. med. Sci., 82: 49-54, 1977.

9. GOMES, J.M. \& PESSOA. S.B.- Um caso de dyarrhea dysenteriforme grave provocada por espirochetas. An. paul. Med. Cirurg., 14: 167-169, 1926.

10. GUCCION, J.G.; BENATOR, D.A.: ZELLER, J.: TERMANINI, B. \& SAINI, N.- Intestinal spirochetosis and acquired immunodeficiency syndrome: ultrastructural studies of two cases. Ultrastruct. Path., 19: 15-22, 1995.

11. HARLAND. W.A. \& LEE, F.D. - Intestinal spirochetosis. Brit. med. J. 3: $718-719,1967$

12. HOVIND-HOUGEN, K; ANDERSEN, A.B.; NIELSEN, R.H. et al. - Intestinal spirochetosis: morphological characterization and cuitivation of the spirochete Brachyspira aalborgi gen. nov., sp. nov. J. clin. Microbiol., 16: 1127-1136, 1982.

13. HSU, S.M. \& FANGER, H. - Use of avidin-biotin-peroxidase complex $(A B C)$ in immunoperoxidase technique: a comparison between $\mathrm{ABC}$ and unlabeled antibody (PAP) procedures. $\mathbf{J}$. Histochem. Cytochem., 29: 557-580, 1981.

14. LEE. F.D.: KRAZZEWSKI, A.: GORDON, J.et al. - Intestinal spirochetosis. Gut, 12: 126-133, 1971.

15. LEE, J.I. \& HAMPSON, D.J. - Genetic characterization of intestinal spirochaetes and their association with disease. J. med. Microbiol. 40: $365-371,1994$

16. LINDBOE, C.F.; TOSTRUP, N.E. ; NERSUND, R. \& REKKAVIK, G. - Human intestinal spirochaetosis in mid Norway. APMIS, 101: 858-864, 1993

17. LINDBOE, C.F.; ENGESVOLL, I; DARELL, M. \& KOPSTAD, G. - Immunoglobulin containing cells in the colonic mucosa in patients with human intestinal spirochetosis. APMIS, 102: 849-854, 1994.

18. LINS, A. - Sobre o Spirocheta eurygyrata e a dysenteria espirillar. Arch. bras. Med., 14: 420-426, 1924

19. MAZZA, S. - Espiroquetosis apendiculares. Pren. méd. argent., 17: $464-468,1930$.

20. NATHWANI, D.; GREEN, S.T. \& BOYD, J.D - Intestinal spirochaetosis in a man with acquired immune deficiency syndrome (AIDS). J. Infect, 21: 318-319, 1990.

21. NIELSEN, R.H.; ORHOLM, M.; PEDERSEN, J.O. et al. - Coloretal 
DE BRITO, T.; SANDOVAL, M. P.; SILVA, A. G.; SAAD, R. C. \& COLAIACOVO, W. - Intestinal spirochetosis: first cases reported in Brazil and the use of immunohistochemistry as an aid in histopathological diagnosis. Rev. Inst. Med. trop. S. Paulo, 38(1): 45-53, 1996.

spirochetosis: clinical significance of the infestation. Gastroenterology, 85: 62-67, 1983.

22. NIELSEN, R.H.; LUNDBECK, F.A.; TEGLBJAERG, P.S; GINNERUP, P. \& HOVIND-HOUGEN, K. - Intestinal spirochetosis of the vermiform appendix. Gastroenterology, 88: 971-977, 1985.

23. RODGERS, F.G.; RODGERS, C.; SHELTON, A.P. \& HAWKEY, C.J. - Proposed pathogenic mechanism for the diarrhea associated with human intestinal spirochetes. Amer. J. clin. Path., 86: 679. $682,1986$.

24. SURAWICZ, C.M.; ROBERTS, P.L.; ROMPALO, A. et al. - Intestinal spirochetosis in homosexual men. Amer. J. Med., 82: 587 592, 1987.
25. TAKEUCHI, A.; JERVIS, H.R.; NAKAZAWA, H. \& ROBINSON, D.M. - Spiral-shaped organisms on the surface colonic epithelium of the monkey and men. Amer. J. clin. Nutr., 27: 1287-1296, 1974.

26. TEgljaerg, P.S. - Intestinal spirochetosis. Curr. Top. Path., 81: $247-256,1990$.

27. WILLÉN, R.; CARLÉN, B.; CRONSTEDT, J. \& WILLÉN, H. Intestinal spirochetosis of the colon diagnosed with colono-ileoscopy and multiple biopsies. Endoscopy, 17: 86-88, 1985.

Recebido para publicação em 29/01/1996 Aceito para publicação em 07/03/1996. 